\title{
ANALISIS DAN PERANCANGAN APLIKASI PENDUKUNG ERP SAP R/3 MODUL SALES AND DISTRIBUTION PT. UNITED TRACTORS, TBK
}

\author{
Johan $^{1}$; Yokie Susanto ${ }^{2}$; Yusmin Joe ${ }^{3}$; Robby ${ }^{4}$ \\ ${ }^{1}$ Jurusan Sistem Informasi, Fakultas Teknologi Informasi, Universitas Tarumanagara \\ Jln. S. Parman No. 1, Jakarta Barat 11440 \\ johanj@binus.edu
}

\begin{abstract}
The purpose of this research is to analyse sales process having been implementing Sales and Distribution module of ERP SAP R/3 and also to design a supporting application for sales process at PT United Tractor, Tbk. The benefit of this application is to help sales person and customer in doing inquiries, quotation and sales order also material information through short message. The method of this research is data capturing, literature review, object oriented analysis and design and Rational Unified process including UML (Unified Modeling Language) for application design. Based on the problem, we designed a web based and sms gateway application to support Sales and Distribution module ERP SAP R/3 to help customer and sales person in doing sales transaction and information inquiry.
\end{abstract}

Keywords: OOAD, Rational Unified Process, SAP, SMS Gateway, Sales and Distribution

\begin{abstract}
ABSTRAK
Tujuan Penelitian ialah menganalisis proses penjualan yang sudah menggunakan ERP SAP $R / 3$ module Sales and Distribution. Serta Merancang aplikasi pendukung untuk proses penjualan pada PT United Tractors, Tbk. Perancangan ini berguna untuk memudahkan salesman dan konsumen melakukan Inquiry, Quotation, Sales Order dan infomasi material melalui sms yang digunakan oleh salesman. Metodologi yang dipergunakan adalah dengan terlebih dahulu mengumpulkan data dan informasi dari sumber terkait, kemudian mempelajari konsep melalui kepustakaan dan selanjutnya analisis dan perancangan dengan pendekatan Object Oriented Analysis and Design (OOA\&D). Metodologi pengembangan aplikasi yang digunakan adalah Rational Unified Language (RUP) dengan notasi Unifed Modelling Language (UML). Berdasarkan analisis masalah, dilakukan analisis dan perancangan aplikasi pendukung ERP SAP R / 3 Module Sales and Distribution yang menghasilkan aplikasi pendukung ERP SAP R / 3 Module Sales and Distribution berbasis web dan aplikasi desktop sms Gateway. aplikasi pendukung ERP SAP $R / 3$ Module Sales and Distribution dibuat untuk mempermudah konsumen dan salesman dalam melakukan transaksi penjualan dan informasi material.
\end{abstract}

Kata kunci: OOAD, Rational Unified Process, SAP, SMS Gateway, Sales dan Distribution 


\section{PENDAHULUAN}

Pada banyak perusahaan sekarang ini, penggunaan teknologi dan sistem informasi sekarang ini banyak difokuskan untuk membantu mempermudah pekerjaan mereka dalam menjalankan operasi bisnis mereka. Banyak perusahaan yang memiliki proses bisnis yang besar dan kompleks yang memerlukan bantuan dari peralatan teknologi untuk mempermudah dan memperlancar proses dan kegiatan bisnis yang mereka lakukan.

Internet sudah banyak dimanfaatkan oleh banyak perusahaan untuk mendukung proses bisnis mereka yang berhubungan dengan para konsumennya. Dari konsep inilah maka perusahaan P.T. United Tractors, Tbk (UT), berencana menggunakan media internet untuk membantu proses bisnis dan hal - hal lain yang berhubungan dengan konsumen perusahaan. Penggunaan internet ini mencakup bagaimana bagian penjualan (sales) dapat dengan mudah dan cepat menangani pesanan dari konsumen dimana pun orang bagian penjualan berada. Selain itu, penggunaan media komunikasi internet juga dimaksudkan agar memberi kemudahan bagi konsumen dalam melakukan pemesanan kepada perusahaan. Hal ini dikarenakan proses bisnis perusahaan yang besar dan kompleks sehingga dengan kehadiran media internet ini dapat meminimalkan proses penjualan yang ada dan tidak serumit atau sekompleks yang dahulu. Sebagai tambahan, proses penjualan perusahaan tidak terpusat pada satu tempat saja, tetapi perusahaan UT memiliki banyak perusahaan cabang yang terletak diluar pulau Jawa di wilayah Indonesia yang dapat menangani masalah penjualan untuk para konsumennya di daerahnya masing - masing.

Dengan adanya aplikasi yang dibuat dengan menggunakan media ini, maka orang atau pihak Departemen Penjualan dapat melakukan dan menawarkan produk yang dijual tanpa harus kembali ke kantor utama untuk mengecek keadaan stok barang sehingga akan mempermudah dan mempercepat proses penjualan dan akan mengurangi biaya lain yang digunakan untuk pengecekan jumlah barang perusahaan.

Keuntungan lain yang didapat perusahaan dari penggunaan aplikasi pendukung adalah konsumen dengan sendirinya dapat melakukan pemesanan secara online dimana dia berada dengan syarat ada jaringan internet yang terhubung dan berfungsi. Dengan adanya hal ini akan semakin mempermudah bagian penjualan dalam mengolah data penjualan, sehingga pesanan konsumen dapat segera diproses. Hal tersebut akan memnberikan kepuasan tersendiri bagi konsumen karena pesanan mereka dapat diproses dengan cepat.

Berdasarkan masalah di atas, maka akan dirancang aplikasi pendukung untuk digabungkan dengan dasar sistem perusahaan. Aplikasi ini akan berhubungan dengan sistem internal perusahaan pada perusahaan UT sebagai upaya untuk memberikan salah satu solusi pada bagian penjualan perusahaan agar dapat memberikan peningkatan kualitas pelayanan yang cepat kepada para konsumennya yang tidak terikat oleh masalah jarak dan waktu.

Tujuan utama dari penelitian ini adalah: (1) Menganalisis secara umum proses penjualan dengan menggunakan modul Sales and Distribution yang sedang berjalan di P.T. United Tractors Tbk; (2) Merancang aplikasi pendukung yang diharapkan dapat mempermudah proses penjualan dengan menggunakan SAP R/3 modul Sales and Distribution yang dapat diakses melalui web; dan (3) Merancang aplikasi pendukung yang diharapkan dapat mempermudah proses pengecekan informasi material yang dapat diakses melalui SMS. 


\section{METODE}

\section{Metode Pengumpulan Data}

Peneliti menggunakan metode studi pustaka untuk mengumpulkan bahan dan informasi mengenai hal-hal yang terkait dengan melakukan studi literature, yaitu mencari informasi melalui buku-buku dan jurnal yang berkaitan dengan topik yang diteliti. Selain itu peneliti juga melakukan obsevasi dan wawancara ke PT United Tractors Tbk untuk mendapatkan informasi dan data mengenai kondisi, proses bisnis yang berlangsung dimana proses tersebut dikhususkan pada proses penjualan dan sistem yang berjalan di perusahaan saat ini. Wawancara dilakukan kepada pihak yang berwenang di bagian penjualan yaitu Kepala Aplikasi Software.

\section{Metode Analisis}

Metode analisis dan perancangan yang digunakan untuk menganalisis sistem yang sedang berjalan pada PT. United Tractors Tbk sampai pada perancangan aplikasi adalah dengan menggunakan metode berbasis objek (object-oriented), sementara keseluruhan rangkaian proses pembuatan aplikasi dilaksanakan berdasar Rational Unified Process (RUP). Hal ini dikarenakan bahasa perancangan RUP sesuai untuk menggambarkan sistem yang sedang berjalan pada perusahaan. Perusahaan saat ini sudah menggunakan suatu sistem informasi tersendiri sehingga penggambaran dengan bahasa perancangan RUP sesuai dengan kondisi sistem perusahaan. Pada analisis ini, akan digunakan fase inception, dan fase elaboration yang meliputi business modeling, analisis kebutuhan dengan menggunakan metode SWOT (Strength, Weakness, Opportunity, Thread), business actors, business use-cases, dan use cas model.

\section{Metode Perancangan}

Keseluruhan perancangan aplikasi yang baru menggunakan dengan menggunakan metode Rational Unified Process (RUP). Pada tahap awal dalam metode perancangan RUP, maka perancangan yang dilakukan adalah perancangan arsitektur aplikasi dan penyusunan tampilan (interface) aplikasi dengan dengan penulisan baris program, yang terdapat pada fase construction. Fase berikutnya adalah fase transition dimana akan berisi rencana implementasi dari aplikasi pendukung berupa web dan SMS Gateway yang telah dirancang. Rencana implementasi akan berisi mengenai kebutuhan dari aplikasi ini agar dapat berjalan pada perusahaan sesuai dengan yang diinginkan.

\section{HASIL DAN PEMBAHASAN}

\section{Aplikasi SAP}

Menurut Wlliams (2008: 2) SAP adalah software dari produk ERP yang tanpa sambungan mengintegrasikan perbedaan fungsi di dalam bisnis (seperti penjualan, pembelian, dan produksi). SAP menyediakan fungsi yang lengkap dalam masing-masing area bisnis tanpa mengorbankan sistem yang telah terintegrasi.

Aplikasi ini update dan proses transaksinya real-time, yang mengijinkan integrasi tanpa dengan usaha yang berarti dan komunikasi antara area bisnis. Contohnya, dapat membuat dokumen billing dan pembebasan dari akunting dan mengamati update nilai billing dalam analisa konsumen dengan segera., tanpa menunggu proses akhir minggu atau akhir bulan. 


\section{Proses Sales Order}

mySAP ERP (Enterprise Resource Planning) menyediakan wawasan yang unggul ke dalam proses sales back-office, seperti yang termasuk berikut ini: inquiries, quotations, order generation, contract and billing cycle management. Manfaat bisnis memiliki gambaran yang lengkap dari sebuah siklus hidup dari konsumen, termasuk di dalam nya seperti status order, billing, payment and credit management. Dalam tambahannya pada fitur back-office, mySAP ERP juga mendukung penjualan dalam internet, mencatat penjualan melalui peralatan yang mobile seperti PDA, handphone dan lainnya.

Skenario proses Sales Order menjelaskan proses yang lengkap, mulai dari aktivitas sebelum penjualan, membuat sales order, dilanjutkan dengan sales order fulfillment dan diakhiri dengan faktur dari sales order dan proses yang berkelanjutan ke dalam financial accounting (lihat Gambar 1).

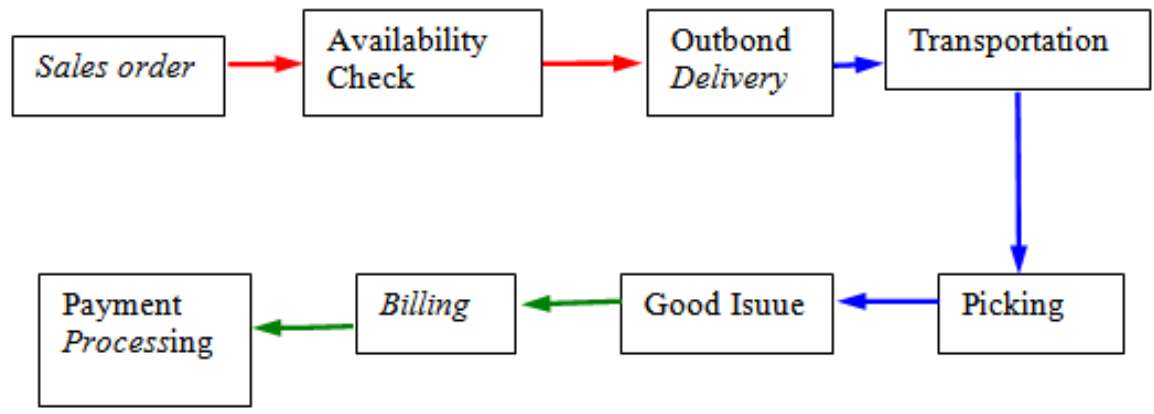

Gambar 1 Siklus Sales Order Process

\section{Latar Belakang Perusahaan}

PT. United Tractors, Tbk atau United Tractors Group adalah supplier utama sebagai penyedia perlengkapan atau peralatan berat dan penyedia pelayanan yang bersangkutan dengan alat - alat berat di Indonesia dengan aset total melebihi Rp 5.58 triliun pada akhir tahun 2000. Sebagai distributor utama peralatan berat di Indonesia, PT. United Tractors, Tbk (UT) memiliki saham - saham penting dalam bidang manufaktur, pertambangan dan energi, dan dalam bidang ekspor industri.

UT didirikan pada tanggal 13 oktober 1972, dengan nama PT. Astra Motor, bekerja sama dengan PT. Astra International sebagai pemegang saham utama. Lalu, PT. Astra Motor berubah nama menjadi PT. United Tractors, Tbk. Sejak saat itu, UT banyak dilibatkan dalam distribusi besar dalam alat - alat besar dan berat produk Komatsu, yang dikenal oleh seluruh dunia, yang berasal dari Komatsu Ltd, Jepang sebagai distributor tunggal di Indonesia.

Pada tahun 1970, UT melebarkan bisnisnya ke dalam bidang manufaktur (perusahaan produksi) dan pabrik mesin, yang berlokasi utama di jalan Raya Bekasi KM. 22, Cakung, Jakarta Timur. UT kembali meningkatkan dan melebarkan tujuan bisnisnya ke dalam bidang pelayanan dan produk pendukung, sehingga pada tahun 1981 UT mendirikan beberapa perusahaan afiliasi (affiliated company / affco).

Selain itu, UT memasuki lingkungan perusahaan pertambangan. UT juga mulai berubah menjadi penyedia solusi untuk masalah alat berat dan pertambangan. Hal itu akan menjadikan UT semakin berkembang di lingkungan bisnis nya dengan mencakup usaha bisnis yang saling berhubungan.

Produk - produk yang biasa dijual oleh UT adalah Bulldozer, Wheel Loader, Swamp Dozer, Forklift dan lain - lain yang berhubungan dengan alat berat. Perusahaan menyediakan peralatan berat 
untuk berbagai macam kebutuhan dari para pelanggan perusahaan lain yang bergerak dalam bidang pertambangan ataupun kontruksi bangunan lainnya seperti jembatan, dan gedung pencakar langit lainnya. Tujuan dari UT sendiri adalah untuk mendapatkan pertumbuhan jangka panjang yang berkelanjutan, menjadi asset penting bagi negara Indonesia, menyediakan pelayanan terbaik kepada para konsumennya, menghormati setiap individu, untuk komitmen dalam kerja kelompok atau tim, dan terakhir adalah untuk secara konstan bekerja keras untuk mencapai kesempurnaan.

\section{Gambaran umum proses penjualan pada PT United Tractor, Tbk.}

Alur proses penjualan yang saat ini berjalan dapat dipersingkat sebagai berikut dari konsumen yang hendak memesan barang lalu diterima oleh perusahaan melalui bagian Controlling Order Processor (COP) yang menerima dokumen tersebut lalu barang tersebut dicek untuk ketersediaannya, jika tersedia maka barang tersebut diproses dalam managing warehouse jika belum tersedia maka proses nya akan dilanjutkan ke bagian inventory untuk menyediakan barang yang diminta melalui proses inventory planning. Setelah diproses dalam inventory planning maka akan dilakukan order stok ke bagian purchasing melalui proses purchasing. Setelah barang dikirim oleh supplier, maka barang akan dicek kesesuaiannya, apabila sesuai maka barang tersebut akan dikirim ke bagian inventory kembali dan diproses melalui managing inventory kemudian dilakukan mutasi stok dan dilanjutkan ke managing warehouse. Dan bagian purchasing akan melakukan proses pembayaran (payment) kepada pihak supplier. Apabila barang yang diterima dari supplier tidak sesuai atau mengalami cacat, maka perusahaan akan melakukan retur. Setelah barang tersedia, maka bagian COP akan membuat customer deliver dan membuat transfer order (TO) kepada bagian inventory. Bagian inventory mengkonfirmasi TO yang telah dibuat dan melakukan Good Issue. Setelah itu, bagian COP akan membuat billing dan harus disetujui terlebih dahulu oleh Parts department Head sebelum membuat Surat Pengantar Barang (SPB) dan faktur pajak (invoice) untuk dikirim ke konsumen bersama dengan barang nya. Jika terdapat kesalahan dalam pengiriman atau barang cacat, maka konsumen dapat meretur kembali dan barang tersebut akan diprosses melalui binning. Setelah masing-masing bagian menyelesaikan proses nya maka akan dibuat laporan yang akan dikumpulkan dan diarsip dalam Parts Organization Report.

\section{Analisa Permasalahan}

Dari uraian proses bisnis yang sedang berjalan tersebut, didapat beberapa masalah yang muncul dan terjadi dalam sistem penjualan barang perusahaan kepada para konsumen perusahaan baik yang dilakukan sendiri oleh perusahaan maupun yang dilakukan oleh karyawan Departemen Penjualan. Masalah - masalah yang dihadapi antara lain adalah: (1) Perlu pelatihan dan biaya tambahan untuk mendapatkan karyawan seperti salesman Departemen Penjualan yang terlatih dalam penggunaan sistem SAP; (2) Proses pemberian informasi dari COP kepada salesman mengenai informasi produk yang ditanyakan oleh salesman memerlukan waktu yang panjang. Hal ini dikarenakan salesman Departemen Penjualan membutuhkan informasi yang cepat mengenai produk produk yang ada dalam perusahaan baik dari segi harga dan persediaan produk tersebut; dan (3). Proses pemesanan dari konsumen yang memakan waktu yang cukup banyak serta perusahaan hanya melayani pemesanan pada jam kerja saja.

\section{Uraian ruang lingkup proses penjualan yang berjalan}

Untuk saat ini, pada perusahaan PT. United Tractors, Tbk (UT) transaksi penjualan terjadi dalam tiga kondisi, yakni: (1) Pertama, ketika seorang konsumen butuh barang dari produk yang dijual perusahaan, konsumen tersebut dapat langsung memesan melalui telepon dengan nomor telepon hotline penjualan perusahaan yang telah disediakan; (2) Selain itu konsumen juga dapat langsung datang mengunjungi perusahaan untuk melakukan transaksi penjualan. Konsumen akan datang langsung ke Departemen Penjualan perusahaan yang akan dilayani oleh salesman dan Customer Order Processor (COP) untuk melakukan pemesanan; (3) Karyawan Departemen Penjualan atau salesman 
dapat langsung mengunjungi konsumen perusahaan di daerah - daerah untuk mempromosikan dan menjual produk perusahaan.

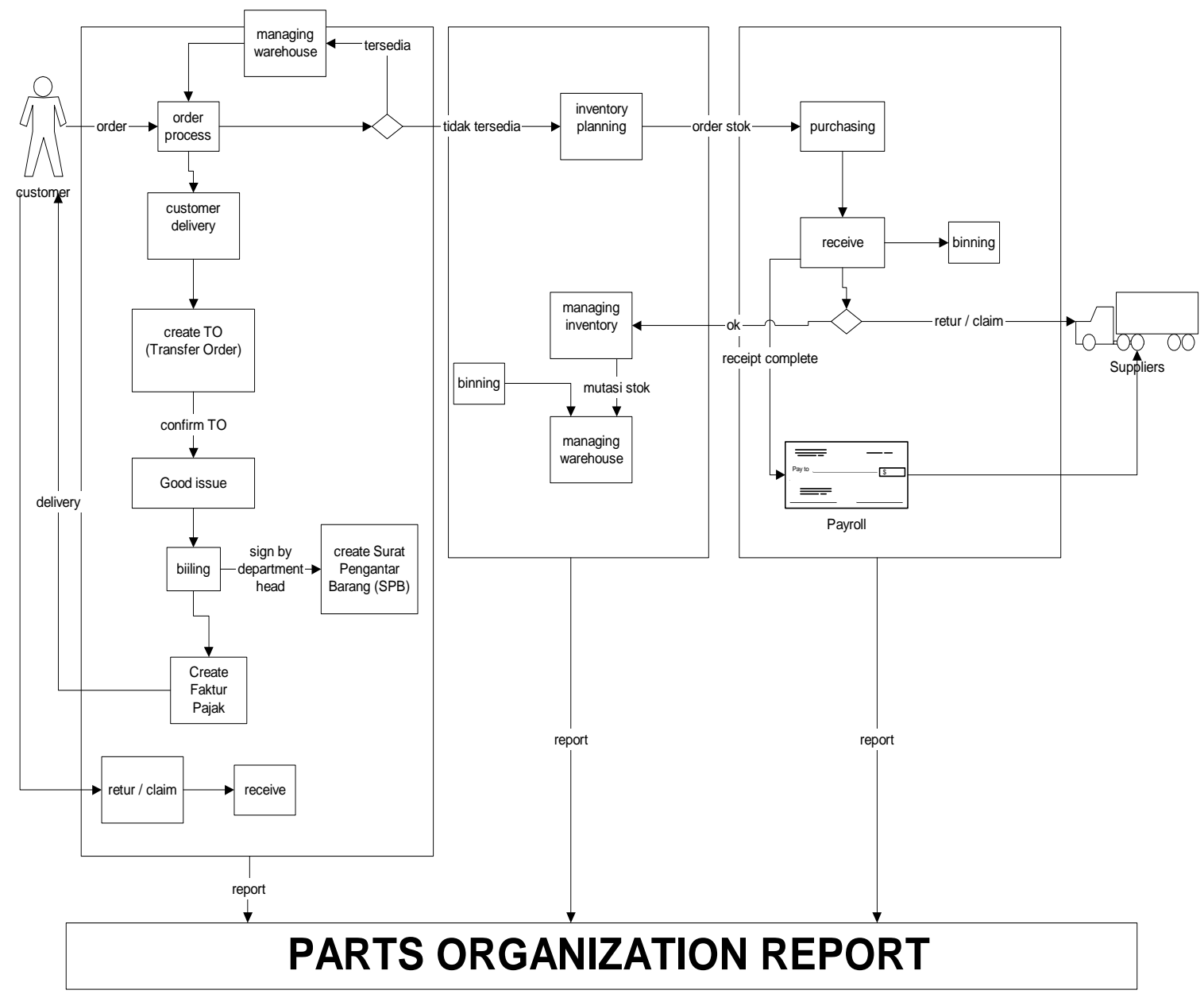

Gambar 2 Gambaran umum proses penjualan

Karyawan Departemen Penjualan atau biasa disebut sebagai salesman yang bertugas langsung untuk menjual barang kepada konsumen di daerah - daerah harus selalu terhubung dengan keadaan perusahaan yang terbaru. Hal tersebut dimaksudkan agar salesman tersebut mengetahui keadaan perusahaan beserta dengan kondisi persediaan atau stok barang perusahaan yang terbaru. Kondisi tersebut berpengaruh terhadap konsumen yang membutuhkan produk atau barang dalam waktu yang cepat dan untuk menghindari kehabisan stok barang.

Salesman biasanya dapat menanyakan langsung kepada COP atau menggunakan teknologi internet untuk berhubungan langsung dengan intranet perusahaan dengan tujuan untuk mengecek keadaan stok barang perusahaan. Hal tersebut dilakukan untuk mengatur pemesanan konsumen akan suatu barang produk perusahaan yang dipesan dalam jumlah besar dan dibutuhkan dalam waktu yang singkat dan cepat.

Selain itu, perusahaan UT juga memiliki konsumen yang ingin melakukan pemesanan tidak melalui telepon dan datang langsung, melainkan dengan menggunakan teknologi informasi komputer dan internet. Mereka kebanyakan mengetik pesanan mereka di komputer dan kemudian mengirimkan melalui jaringan internet kepada perusahaan UT. 
Customer Order Processor (COP) pada Departemen Penjualan akan menanggapi semua pesanan dari konsumen dan membuat Quotation, Inquiry, ataupun Sales Order dalam bentuk dokumen untuk para konsumennya yang sesuai dengan permintaan mereka. Informasi permintaan dari para konsumen tersebut akan diinputkan ke dalam sistem SAP perusahaan oleh Departemen Penjualan. Kemudian informasi yang berhubungan dengan penjualan atau pemesanan dari konsumen (order konsumen) tersebut akan diteruskan kepada Warehaouse crew pada bagian gudang. Daftar permintaan selain order konsumen akan ditanggapi oleh Departemen Penjualan sesuai dengan prioritas waktu permintaan.

Quotation dan Inquiry memiliki jangka waktu tersendiri sehingga kedua dokumen tersebut tidak akan berlaku selamanya karena keadaan lingkungan perekonomian bisnis perusahaan selalu berubah - ubah. Tidak selamanya harga produk perusahaan tetap dan tidak berubah. Harga produk perusahaan akan berubah sesuai dengan keadaan perekonomian bisnis yang juga berkaitan dengan keadaan ekonomi dunia luar. Hal itu dikarenakan sebagian besar produk perusahaan didatangkan dari luar negeri sehingga harganya akan berubah.

Untuk Inquiry, dokumen tersebut hanya berlaku untuk konsumen melihat harga - harga produk sesaat setelah konsumen mengirimkan permintaan. Informasi tersebut tidak akan berlaku lagi untuk hari esok atau masa depan karena kemungkinan adanya perubahan informasi. Untuk Quotation, dokumen tersebut berlaku dalam jangka waktu satu minggu setelah dokumen tersebut dikeluarkan oleh sistem. Dokumen tersebut akan meminta tanggapan kembali dari konsumen, apakah konsumen tersebut ingin melanjutkan Quotation tersebut menjadi dokumen Sales Order atau tidak. Jika tidak ada tanggapan dari konsumen, maka Quotation tersebut dalam jangka waktu satu minggu tidak akan berlaku lagi dan informasi yang ada di dalamnya tidak berlaku lagi.

Di dalam Inquiry terdapat informasi mengenai detail barang atau produk, harga produk, dan jumlah stok tersedia. Di dalam Quotation terdapat informasi mengenai penawaran harga dari perusahaan kepada konsumen, kuantitas barang yang dapat disediakan (Quantity), detail dan kondisi barang (Part Condition), waktu pengadaan barang (lead time) atas barang yang diminta. Setelah informasi akan permintaan produk perusahaan dari konsumen dimasukan dalam sistem, maka data tersebut akan dianalisa mengenai jadwal dan perencanaan yang berhubungan dengan produk tersebut. Jika ternyata barang tersebut sudah dipesan, maka akan ada informasi mengenai tersedianya barang tersebut. Jika konsumen setuju dengan harga dan kondisi perusahaan, maka dokumen Quotation akan diubah menjadi dokumen Sales Order. Sales Order adalah penjualan barang perusahaan kepada konsumen yang dibuat oleh Departemen Penjualan yang digunakan sebagai bukti transaksi pembelian barang oleh konsumen.

\section{Struktur Use Case Module}

Untuk memperjelas akan aplikasi yang akan dirancang, maka dibuatlah use case diagram berdasarkan actor dan use case yang telah diidentifikasi sebelumnya dalam business use case. Use case diagram ini akan memperjelas actor dan use case nya. Gambar 4 berikut ini adalah use case model berdasarkan actor dan use case yang telah didapat: 


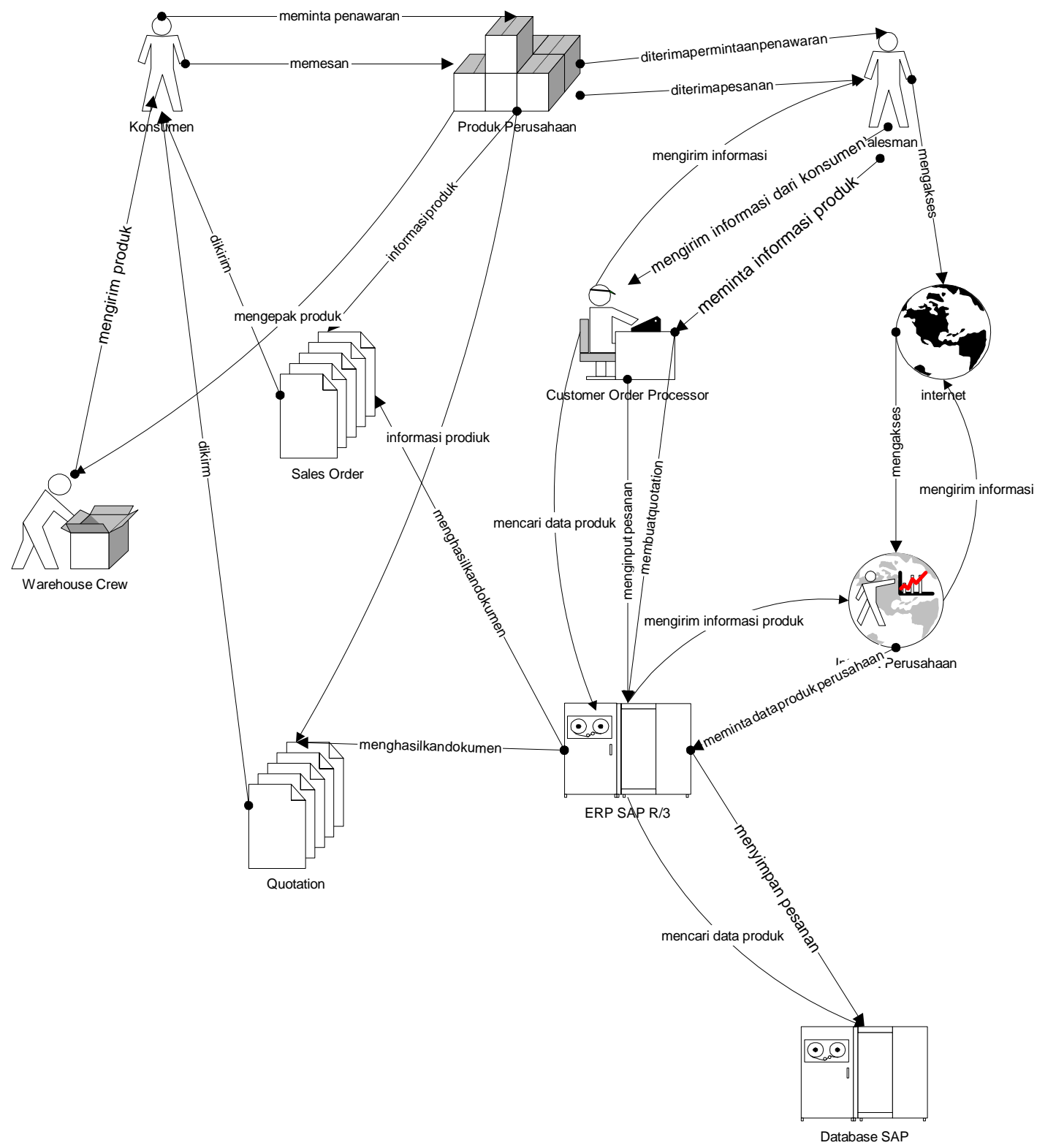

Gambar 3 Ruang lingkup proses penjualan 


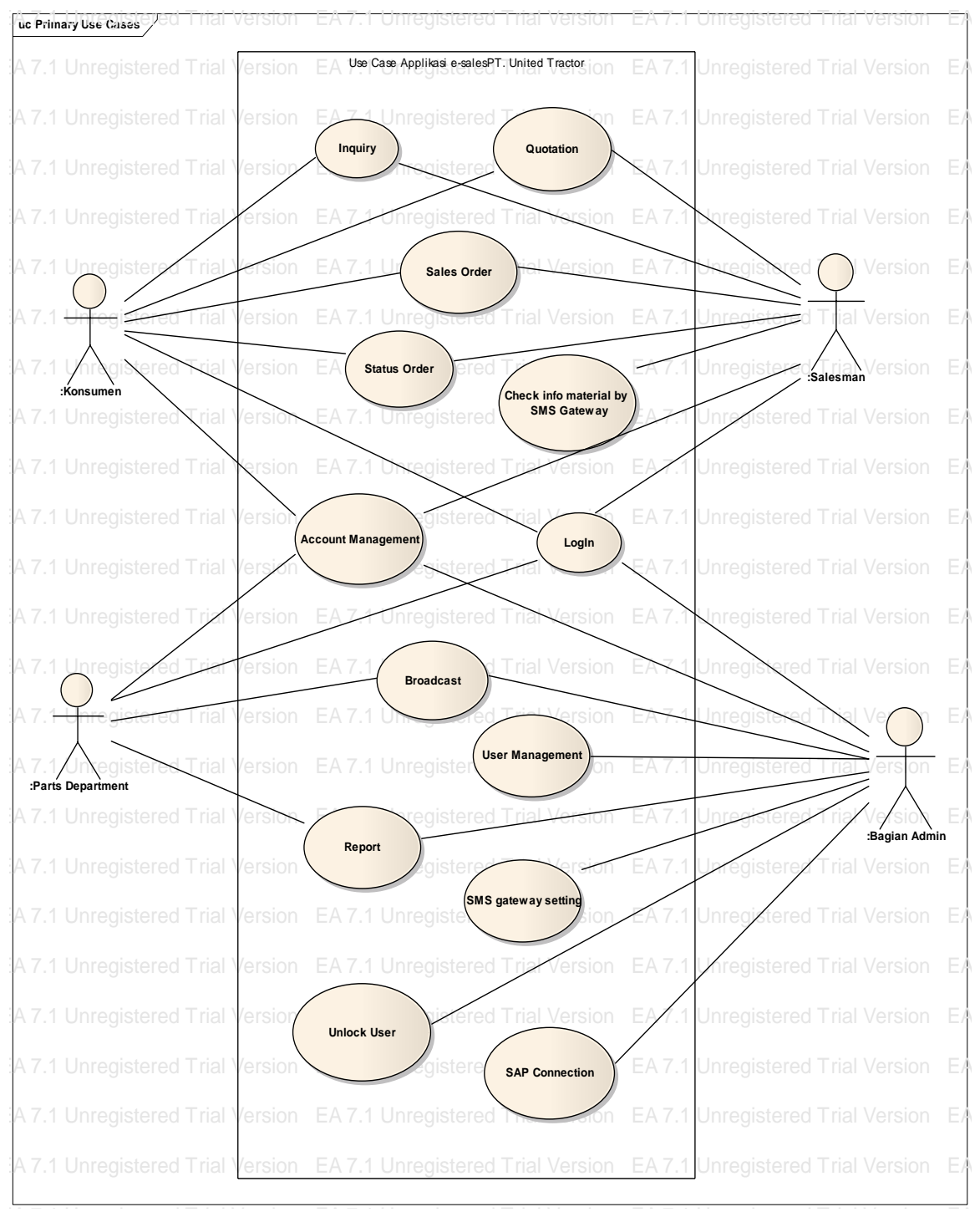

Gambar 4 System use case diagram

\section{Release Notes}

Release Notes dibuat dengan tujuan untuk menjelaskan fitur-fitur serta persyaratan spesifikasi komputer yang dibutuhkan dalam mengimplementasikan aplikasi ini. Aplikasi web dan fitur SMS Gateway ini digunakan oleh karyawan dan konsumen yang mempunyai fungsi dalam masing-masing perannya. Bagi karyawan yang menggunakan aplikasi ini terdiri dari bagian Admin, Parts Department dan salesman. Bagian Admin berhak untuk melakukan registrasi user yang ingin menggunakan aplikasi ini, mengatur koneksi yang menghubungkan antara aplikasi web dengan software SAP R/3 atau antara fitur SMS Gateway dengan software SAP R/3, mengatur SMS Gateway setting yang digunakan oleh pihak salesman, melakukan broadcast melalui SMS Gateway kepada salesman per individu maupun per grup, mengatur user yang berhak menggunakan aplikasi web dan SMS Gateway ini serta dapat mengecek laporan SMS Gateway yang telah dilakukan oleh salesman, Parts Department dan bagian Admin. Bagian Parts Department berhak untuk melakukan broadcast melalui SMS Gateway kepada salesman per individu maupun per grup dan melihat laporan dari SMS Gateway maupun laporan dari hasil Inquiry secara real-time. Bagian salesman dan konsumen mempunyai fungsi yang hampir sama dalam penggunaan aplikasi ini, hanya berbeda dalam fasilitas penggunaan 
SMS yang berhak diakses oleh salesman saja. Bagian salesman dan konsumen dapat melakukan proses Inquiry (pencarian informasi produk yang diperlukan), membuat Quotation, membuat Sales Order dan memantau Status Order yang berkaitan dengan data Sales Order yang telah dipesan sebelumnya.

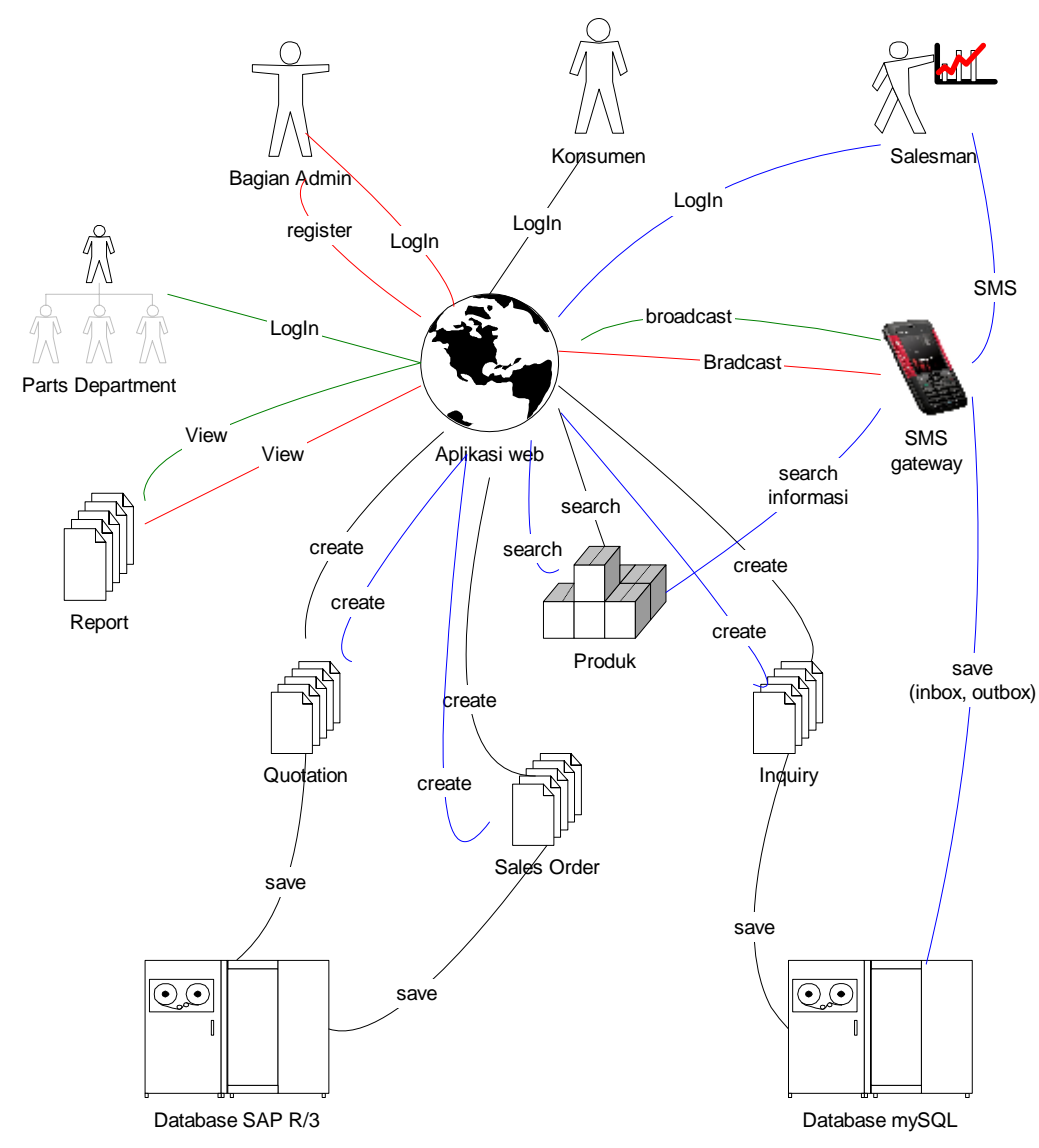

Gambar 5 Sistem penjualan menggunakan aplikasi yang dirancang

\section{SIMPULAN}

Berdasarkan hasil dari analisa dan perancangan aplikasi pendukung ERP (Enterprise Resource Planning) SAP R/3, maka kesimpulan yang dapat diambil adalah: (1) PT. United Tractors Tbk adalah perusahaan yang bergerak dalam beberapa bisnis, seperti penjualan peralatan berat, perusahaan pertambangan, dan akan bergerak ke arah perusahaan penyedia solusi untuk masalah alat berat dan pertambangan. Permasalahannya terletak pada penyediaan informasi produk perusahaan kepada cabang - cabang perusahaan yang tersebar di seluruh Indonesia, dan pemrosesan order konsumen yang memakan waktu yang cukup lama; (2) Dengan adanya aplikasi pendukung ERP SAP R/3, salesman dan konsumen dapat langsung melakukan inquiry, mengisi quotation, dan mengisi sales order secara langsung melalui media internet sehingga akan mempercepat pemrosesan quotation dan sales order yang dilakukan oleh Customer Support atau Customer Order Processor (COP); dan (3) Dengan adanya aplikasi pendukung ERP SAP R/3 yang mencakup desktop application, yakni SMS Gateway, semakin memudahkan salesman perusahaan yang tersebar di daerah - daerah di seluruh Indonesia untuk mengecek dan mendapatkan informasi produk perusahaan dalam hal stok barang yang tersedia. 


\section{DAFTAR PUSTAKA}

Booch, G., Rumbaugh, J., \& Jacobson, I. (1999). The Unified Modeling Language User Guide. New Jersey: Addison-Wesley.

Connolly, T. M., \& Begg, C. E. (2005). Database Systems: A Practical Approach to Design, Implementation, and Management. 4th Edition. Essex: Addison-Wesley.

Kruchten, P. (1999). The Rational Unified Process: An Introduction. Massachusetts: Addison-Wesley.

Lau, L. (2005). Managing Business with SAP: Planning, Implementation, and Evaluation. Hershey: Idea Group Publishing.

Leon, A. (2005). ERP Demystified. New York: McGraw-Hill.

Schneiderman, B. (1998). Designing the User Interface Strategies for Effective Human-Computer Interaction. 3rd Edition. USA: Addison-Wesley.

Whitten, J.L., Bentley, L.D. \& Dittman, K.C. (2004). System Analysis and Design Method. Sixth Edition. McGraw-Hill.

Williams, G. C. (2008). Implementing SAP ERP Sales and Distribution. USA: McGraw-Hill. 